\title{
Implementation of Project Based Learning Model to Increase Students' Competence in Machining Work
}

\author{
Wahyu Dwi Kurniawan, Agung Prijo Budiono \\ Mechanical Engineering Department \\ Universitas Negeri Surabaya \\ Surabaya,Indonesia \\ wahyukurniawan@unesa.ac.id
}

\begin{abstract}
Students' skills in machining work are low. Although they are able to complete the worksheet, the result is much deviate from the science of machining process. In other words they use the principle of origin (size of not precision) without based on the rules in the machining process. The purpose of this research is to improve the work skills of machining process of mechanical engineering students of State University of Surabaya through the application of projectbased learning model viewed from the activities of lecturers, students' activities, and students' learning outcomes (cognitive and psychomotor) after attending lectures of machining practice using project based learning model. This type of research includes classroom action research with the use of practical guides in the teaching and learning process. Based on the results of data analysis and discussion, the researchers can conclude that the implementation of project-based learning model was proven to improve the machining skills of machining process. This is based on the observation of activities of lecturers, students' activities, and students' learning outcomes with the following description; (1) The most dominant lecturer activity in cycle $I$ and cycle II is to monitor students in project completion, $45 \%$ in the first cycle and $55 \%$ in the second cycle. This shows that the role of the lecturer is as the facilitator so that the students become more dominant during the lesson; (2) The most dominant student activity is completing the project monitored by the lecturer, $42 \%$ in the first cycle and $46.5 \%$ in the second cycle. This indicates that the lecturer acts as a facilitator so as to give a lot of time to the students to develop their own potential, especially in machining skills; and (3) The completeness of students' cognitive learning result is classically increased from cycle I to II, with the $90 \%$ as the percentage of classical completeness in cycle $I$ and $100 \%$ in cycle II. For the completeness of psychomotor learning outcomes of students, it also increased with percentage of $70 \%$ in cycle I to $100 \%$ in cycle II. This shows that students' learning outcomes can be declared "competent".
\end{abstract}

Keywords—project based learning model, matching work

\section{INTRODUCTION}

One of the efforts to overcome unemployment and reduce the number of poor people is by directing economic growth by not only creating new job opportunities, but also to restructure the workforce. To answer these challenges, it is necessary for graduates of educational institutions to have the ability and skills to the field of work. Therefore, education should be able to provide supplies (skills) for graduates to face life. Efforts to get closer to the world of education with the world of work must be started from the beginning, so that education is able to produce workforce ready[5].

State University of Surabaya is one of the universities having a vision of developing science, technology, and art (science) which has competitive advantages at national, regional and international level (State University of Surabaya Manual 2006: 1). The educators hope that the learning process implemented by each institution will be better which will be able to improve the quality of the students in each educational institution. With the increasing quality of learners, it is expected that the goal of education will be achieved. The learning environment governed by teachers includes learning objectives, learning materials, learning methodologies, and research learning. These elements are commonly known as the teaching component [8].

To meet the standard of competence, every graduate of State University of Surabaya, especially majoring in Mechanical Engineering, production machine concentration must have machining work skills obtained from machining practice course. The required skills are not only able to operate machine tools, but are also required to understand the stages of the process of machining process work that includes planning, designing, scheduling, completing, and the preparing of the report.

According to the lecturer of machining practice course Department of Mechanical Engineering that, student skills in the machining process work is still low. Although students are able to complete the worksheet, the result is much deviate from the science of machining process, in other words they use the principle of origin (size of not precision) without based on the rules in the machining process.

The various obstacles above are influenced by several factors, including: limited resources available from both students and lecturers, learning models used by lecturers, interaction between lecturers and students who are less good, less conducive workshop condition, machine condition less standardized, instructive lecturers who tend to be instructive, lack of manual guidelines in writing and the limitations of students themselves (knowledge and skills).[7]

There are various ways that can be done to improve the skills of students in this course of practice, among others, is to apply a more innovative learning model and provide practical guidance that can encourage the emergence of student motivation and independence. This is especially for the provision of learning tools, strives for the availability of 
semester learning plans, lecture unit, systematic practicum guide and evaluation sheets [1].

Referring to the development of the State University of Surabaya curriculum and the development needs of the world of work, the program of in mechanical engineering, especially in the course of machining practice requires the reconstruction of learning model in order to meet the demands as described previously. Given the definition of relevance and target achievement of the course, the use of appropriate learning model becomes one of the determinants of the achievement of learning objectives.

Project Based Learning is one of the learning models that includes a series of learning activities planned and designed by educators systematically and interestingly to help learners achieve learning goals in producing a product. By applying the project-based learning model it can provide more opportunities for students to learn independently or in groups to produce a product. Especially the Department of Mechanical Engineering State University of Surabaya which in the development is closely related to the industrial world will always be required to be able to equip its graduates with qualifications of expertise standards, attitudes and behavior in accordance with the needs of the world of work. In an effort to overcome the above problems it is necessary to conduct classroom action research on machining practice course. This research will be attempted to improve the skills of machine tool operation through the application of projectbased learning model.

The purpose of this study is to improve the work skills of machining process of mechanical engineering students State University of Surabaya through the application of projectbased learning model as follows:

- To know lecturer's activity during lecturing practice using project-based learning model.

- To know the activities of students during lecturing practice of machining using project-based learning model.

- To know the student learning outcomes (cognitive and psychomotor) after following the lecturing practice of machining using project-based learning model.

\section{METHOD}

This type of research includes classroom action research with the use of practical guides in the teaching and learning process [10]. The subject of this research is the students of S1 Mechanical Engineering Education Program of Engineering Faculty State University of Surabaya which at the time of this research is being programmed subjects of Machinery Practice were 10 people. This research was conducted in Machining Laboratory Department of Mechanical Engineering A6 Building 1st floor in 2014/2015 gasal semester.

To collect the necessary data this research will employ observation technique (observation) and performance test (job sheet). Observations of this study were conducted at the time of learning. Observation of learning is done directly during learning. As observers in this study is one lecturer pengampu course. Implement an action to know the implementation by using a project-based learning model, which includes: (1) implementation in a project-based learning model, and (2) student activity during the learning process in the machining process. The test result of student learning in this research is to know student's cognitive and psychomotor ability after using project-based learning model [4]

To find out the result of application of project-based learning model in learning activity data analysis is required. This study employs qualitative descriptive analysis techniques to determine the students' learning description, lecturer activities and student activities during the learning process [6].

\section{RESUlt AND Discussion}

\section{A. Result}

\section{1) Cycle I}

\section{a) Stage of Planning/Preparation}

At this stage the researcher along with the lecturer of the course did the preliminary research to find out the characteristics of the students, identify the problem, set the goal, then formulate the indicators to measure the success of learning in accordance with the basic competencies that have been set. In addition, researchers also prepare learning tools, (lecture course units, semester learning plan, and practical guides) and research instruments (lecturer observation sheets, student activities, and worksheet test sheets).

\section{b) Stage of Action}

In the early learning activities of the project-based learning model, the teacher starts by conveying the learning objectives and motivating the students about the importance of machine skills until the lecturer evaluates and reflects the students 'work in the cognitive and psychomotor aspects to know the students' success in teaching and learning process.

\section{c) Observation Stage}

Observation focused on 5 (five) students who have been selected at random during the learning took place. The result of observation of lecturer activity can be seen in Table I while student activity can be seen in Table II.

TABLE I. OBSERVATION RESUlt OF LECTURER ACTIVITY IN CYCLE I

\begin{tabular}{|c|l|c|}
\hline No. & \multicolumn{1}{|c|}{ Activity observed } & Value (\%) \\
\hline 1 & Convey goals and motivate students & 5 \\
\hline 2 & Plan the project & 5 \\
\hline 3 & Guiding students in project completion design & 10 \\
\hline 4 & Guiding students in project design & 15 \\
\hline 5 & Demonstrate machining work skills & 5 \\
\hline 6 & Monitor students in project completion & 45 \\
\hline 7 & Evaluate and reflect on student work & 15 \\
\hline \multicolumn{2}{|c|}{ Total } & 100 \\
\hline
\end{tabular}

TABLE II. ObSERVATION Result of StUdent ACTIVITy In CyCLE 1

\begin{tabular}{|c|l|c|}
\hline No. & \multicolumn{1}{|c|}{ Activity observed } & Value (\%) \\
\hline 1 & $\begin{array}{l}\text { Listen / pay attention to the explanation of } \\
\text { lecturer / friend }\end{array}$ & 13.00 \\
\hline 2 & Designing project completion & 17.50 \\
\hline 3 & Make a schedule & 14.00 \\
\hline 4 & Completed the project & 42.00 \\
\hline 5 & Compile reports & 10.50 \\
\hline 6 & Presentation & 3.00 \\
\hline 7 & $\begin{array}{l}\text { Behaviors that are not relevant to learning } \\
\text { (joking, racketing etc.) }\end{array}$ & 0.00 \\
\hline \multicolumn{1}{|c|}{ Total } & 100 \\
\hline
\end{tabular}




\section{d) Evaluation Stage}

Recapitulation of student evaluation test result in cycle I can be seen in table below.

TABLE III. RESULTS OF COGNITIVE LEARNING IN CYCLE 1

\begin{tabular}{|l|l|c|}
\hline No. & \multicolumn{1}{|c|}{ Activity observed } & Value \\
\hline 1 & Average value & 82.30 \\
\hline 2 & Number of graduating students $(>70)$ & 9 \\
\hline 3 & Number of students Not graduated & 1 \\
\hline 4 & $\%$ Classic exhaustiveness & 90 \\
\hline
\end{tabular}

TABLE IV. RESULTS OF PSYCHOMOTOR LEARNING IN CYCLE 1

\begin{tabular}{|l|l|c|}
\hline No. & \multicolumn{1}{|c|}{ Activity observed } & Value \\
\hline 1 & Average value & 72.80 \\
\hline 2 & Number of graduating students $(>70)$ & 7 \\
\hline 3 & Number of students Not graduated & 3 \\
\hline 4 & $\%$ Classic exhaustiveness & 70 \\
\hline
\end{tabular}

\section{e) Reflection}

Based on Table I it can be seen that the most dominant activity is the activity of monitoring the students in project completion (45\%). In this activity the activities undertaken by the lecturer is to monitor the extent to which the work done by the students, in addition it is often the lecturer reminds the students to be careful in working with the priority of safety work.

Based on Table II, it can be seen that the most dominant activity is the project completion activity (42\%). In this activity the activities undertaken by students are doing the project (job sheet) using lathe with priority to safety work and monitored by lecturers in order to avoid work accident.

Students' learning outcomes in cycle I were measured using the scoring sheets for each. Completeness of student learning is based on minimum mastery standard set in the Department of Mechanical Engineering Faculty of Engineering State University of Surabaya. Completeness criteria learn individually is if reaching completeness at least 70 as shown in Table 3.4. Meanwhile, to determine student's learning completeness in class is said to be complete if the percentage of students who get a minimum score of 70 as much as $\geqslant 85 \%$.

Based on Table III, it is known that the average value of student learning outcomes cognitive domain of 82.30 , the number of completed students as many as 9 people from 10 people, so that $90 \%$ classical completeness. This shows that students' learning completeness in the cognitive domain has been achieved because $\geqslant 85 \%$.

Based on Table IV, it is known that the average score of psychomotor students learning achievement is 72,80 , the total number of complete students is 7 people from 10 people, so that $70 \%$ classical completeness. This shows that students' learning mastery in the psychomotor realm has not been achieved because $\leqslant 85 \%$.

\section{f) Revision}

Based on the results of classical completeness in the realm of cognitive by $90 \%$ indicates that the learning objectives have been achieved while the psychomotor realm of $70 \%$ indicates that the learning objectives have not been achieved because of the classical completeness standard set by the Department of Mechanical Engineering $85 \%$.
Therefore, there are aspects that need to be revised for the next cycle are:

- Lecturers should be more intensive in guiding students when designing, arranging schedules and working on projects, because in cycle I this is the first time students operate the lathe and less understand the stages in the completion of the worksheet so the results are not optimal. Therefore, in the next cycle students are expected to more skillfully operate the lathe and better understand the phases of completion of the worksheet according to the procedure so that it can complete the worksheet well.

- Lecturers should motivate students more to be more confident in completing the worksheet, because in the first cycle students are still awkward in operating the lathe and feared if an accident occurred.

\section{2) Cycle II}

\section{a) Stage of Planning/Preparation}

At this stage, the researcher develops the learning scenario according to the result of reflection in cycle I by setting the objectives, then formulate the indicators to measure the success of the learning in accordance with the basic competencies that have been set. In addition, researchers also prepared learning tools, (lecture course units), and research instruments (observation sheet of lecturer activities, student activities, and assessment sheets (cognitive and psychomotor).

\section{b) Stage of Action}

In the early learning activities of the project-based learning model, the teacher starts by conveying the learning objectives and motivating the students about the importance of machine skills until the lecturer evaluates and reflects the students 'work in the cognitive and psychomotor aspects to know the students' success in teaching and learning process.

\section{c) Observation Stage}

Observation focused on 5 (five) students who have been selected at random during the learning took place. The result of observation of lecturer activity can be seen in Table V while student activity can be seen in Table VI.

TABLE V. OBSERVATION RESUlt OF LECTURER ACTIVITY IN CYCLE II

\begin{tabular}{|c|l|c|}
\hline No. & \multicolumn{1}{|c|}{ Activity observed } & Value (\%) \\
\hline 1 & Convey goals and motivate students & 5 \\
\hline 2 & Plan the project & 5 \\
\hline 3 & Guiding students in project completion design & 10 \\
\hline 4 & Guiding students in project design & 10 \\
\hline 5 & Demonstrate machining work skills & 5 \\
\hline 6 & Monitor students in project completion & 55 \\
\hline 7 & Evaluate and reflect on student work & 10 \\
\hline \multicolumn{2}{|c|}{ Total } & 100 \\
\hline
\end{tabular}

TABLE VI. ObSeRvation Result of StUdent Activity in Cycle II

\begin{tabular}{|c|l|c|}
\hline No. & \multicolumn{1}{|c|}{ Activity observed } & Value (\%) \\
\hline 1 & Convey goals and motivate students & 13.00 \\
\hline 2 & Plan the project & 11.50 \\
\hline 3 & Guiding students in project completion design & 11.00 \\
\hline 4 & Guiding students in project design & 46.50 \\
\hline 5 & Demonstrate machining work skills & 16.00 \\
\hline 6 & Monitor students in project completion & 2.00 \\
\hline 7 & Evaluate and reflect on student work & 0.00 \\
\hline \multicolumn{2}{|c|}{ Total } & 100 \\
\hline
\end{tabular}




\section{d) Evaluation Stage}

At this stage, the lecturer evaluates the student's work to know the completeness of student learning outcomes in the cognitive and psychomotor aspects. The data of evaluation result in cycle II is obtained from the value of student learning result which can be seen in the attachment. Recapitulation of student evaluation test result in cycle II can be seen in table below.

TABLE VII. RESULTS OF COGNITIVE LEARNING IN CYCLE II

\begin{tabular}{|l|l|c|}
\hline No. & \multicolumn{1}{|c|}{ Activity observed } & Value \\
\hline 1 & Average value & 83.00 \\
\hline 2 & Number of graduating students $(>70)$ & 10 \\
\hline 3 & Number of students Not graduated & 0 \\
\hline 4 & $\%$ Classic exhaustiveness & 100 \\
\hline
\end{tabular}

TABLE VIII. RESULTS OF PSYMOTOR LEARNING IN CYCLE II

\begin{tabular}{|l|l|c|}
\hline No. & \multicolumn{1}{|c|}{ Activity observed } & Value \\
\hline 1 & Average value & 83.00 \\
\hline 2 & Number of graduating students $(>70)$ & 10 \\
\hline 3 & Number of students Not graduated & 0 \\
\hline 4 & $\%$ Classic exhaustiveness & 100 \\
\hline
\end{tabular}

\section{e) Reflection}

Based on Table $\mathrm{V}$ the observation of lecturer activity in learning in cycle II, it can be seen that the most dominant activity is the same as in the first cycle is the activity of monitoring the students in project completion with percentage $55 \%$. In this activity the activities undertaken by the lecturer is to monitor the extent to which the work done by the students, in addition it is often the lecturer reminds the students to be careful in working with the priority of safety work.

Based on Table IV, it can be seen that the most dominant activity is the same as in the first cycle is the activity of completing the project with a percentage of $46.5 \%$. This shows improvement in student activity when compared to the first cycle of $42 \%$. In addition, students' self-confidence in finishing becomes higher because they are increasingly familiar with the job of completing the job sheet so that they are no longer awkward in machining work.

Students' learning outcomes in cycle II were measured using an assessment sheet. Completeness of student learning is based on minimum mastery standard set in the Department of Mechanical Engineering Faculty of Engineering Unesa. Individual learning completeness criteria is if reaching completeness at least 70 as shown in Table V. Meanwhile, to determine student's learning completeness in class is said to be complete if the percentage of students who get a minimum score of 70 as much as $\geqslant 85 \%$.

Based on Table VII, it is known that the average score of students' cognitive learning outcomes in cycle II is 81.30 , the number of completed students is 10 people from 10 people, so that $100 \%$ classical completeness. This shows that students' learning completeness in the cognitive domain has been achieved because $\geqslant 85 \%$ so no cycle III is required.

Based on Table VIII, it is known that the average score of students learning outcomes in psychomotor cycle II is 83.00 , the number of completed students as many as 10 people from 10 people, so that $100 \%$ classical completeness. This shows that students' learning mastery in the psychomotor realm is achieved because $\geqslant 85 \%$ so no cycle III is required.

\section{B. Discussion}

1) Lecturer's Activities

Recapitulation of lecturer activity observation during learning can be seen in Table IX below.

TABLE IX. OBSERVATION RESUlt OF LECTURER ACTIVITY

\begin{tabular}{|r|l|c|c|}
\hline \multirow{2}{*}{ No } & \multicolumn{2}{|c|}{ Activity observed } & \multicolumn{2}{c|}{ Cycle (\%) } \\
\cline { 3 - 5 } & & I & II \\
\hline 1 & Convey goals and motivate students & 5 & 5 \\
\hline 2 & Plan the project & 5 & 5 \\
\hline 3 & Guiding students in project completion design & 10 & 10 \\
\hline 4 & Guiding students in project design & 15 & 10 \\
\hline 5 & Demonstrate machining skills & 5 & 5 \\
\hline 6 & Monitor students in project completion & 45 & 55 \\
\hline 7 & Evaluate and reflect on student work & 15 & 10 \\
\hline \multicolumn{2}{r}{ Total } & 100 & 100 \\
\hline
\end{tabular}
1

For more details, lecturer activity is also shown in Figure

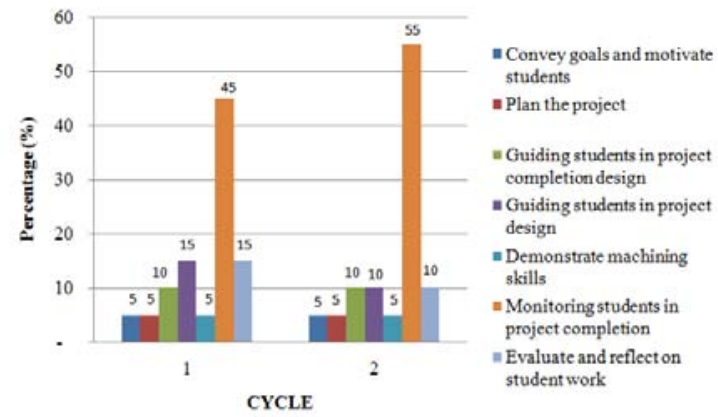

Fig. 1. Recapitulation Chart of Lecturer Activity

Referring the result of observation of lecturer activity in learning in cycle I, it can be seen that the most dominant activity is the activity of monitoring the students in project completion (45\%). While in cycle II, it can be seen that the most dominant activity is the same as in the first cycle is the activity of monitoring the students in the completion of the project with the percentage of $55 \%$. In this activity the activities undertaken by the lecturer is to monitor the extent to which the work done by the students, in addition it is often the lecturer reminds the students to be careful in working with the priority of safety work. This shows that the application of project-based learning model proved to facilitate lecturers in the achievement of learning objectives, especially subjects that demand the skills of students by positioning the lecturer as a facilitator so that students become more active.

\section{2) Students Activities}

Recapitulation of students activity observation during learning can be seen in Table below. 
TABLE X. Observation Result of Students Activity

\begin{tabular}{|c|c|c|c|}
\hline \multirow{2}{*}{\multicolumn{2}{|c|}{ Activity observed }} & \multicolumn{2}{|c|}{ cycle $(\% / 0)$} \\
\hline & & \multirow{2}{*}{$\begin{array}{c}\boldsymbol{I} \\
13.00\end{array}$} & \multirow{2}{*}{$\begin{array}{c}\text { II } \\
13.00\end{array}$} \\
\hline 1 & $\begin{array}{l}\text { Listen pay attention to the explanation of } \\
\text { lecturer friend }\end{array}$ & & \\
\hline 2 & Designing project completion & 17.50 & 11.50 \\
\hline 3 & Make a schedule & 14.00 & 11.00 \\
\hline 4 & Completed the project & 42.00 & 46.50 \\
\hline 5 & Compile reports & 10.50 & 16.00 \\
\hline 6 & Presentation & 3.00 & 2.00 \\
\hline 7 & $\begin{array}{l}\text { Behaviors that are not relevant to learning } \\
\text { (joking, racketing etc.) }\end{array}$ & 0.00 & 0.00 \\
\hline & Total & 100.00 & 100.00 \\
\hline
\end{tabular}

Referring observation result of student activity in learning in cycle I, it can be seen that the most dominant activity is project completion activity $(42 \%)$. While in cycle II it can be seen that the most dominant activity the same as in the first cycle is the activity of completing the project with a percentage of $46.5 \%$. The activities were undertaken by students is doing the project (job sheet) using lathe with priority safety work and monitored by lecturers in order to avoid work accidents.

For more details, students activity is also shown in Fig 2.

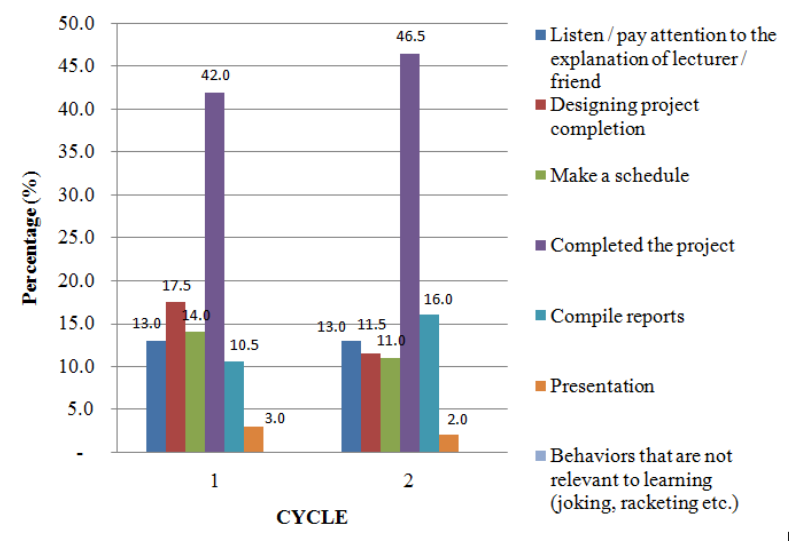

Fig. 2. Recapitulation Chart of Students Activity

The activity of completing the project provides an opportunity for students to be more motivated to learn, but it is also in accordance with the principle of direct involvement that states that the knowledge gained will be more meaningful, lasting longer in memory if experiencing, observing, trying, self-practicing [6]. All observed student activities clearly illustrate that the process of teaching and learning with a project-based learning model is a teachinglearning process that creates a learning atmosphere that prioritizes hands-on experience using problems as a first step in collecting and integrating new knowledge based on experience in real activity.

This shows that the implementation of project-based learning model proved to increase student activity in the effort of achieving the learning objectives, especially the subjects that demand the skills of the students because the lecturer acts as a facilitator so as to give a lot of time to the students to develop their own potential, especially in machining work skills. [3]

\section{3) Results of learning}

Student learning outcomes obtained on learning in terms of three aspects of cognitive and psychomotor. To recapitulate students cognitive learning outcomes can be seen in Table XI while for the recapitulation of students' psychomotor learning results can be seen in Table XII.

TABLE XI. Student COGNITIVE LEARNING RESUlts

\begin{tabular}{|l|l|c|c|}
\hline \multirow{2}{*}{ No. } & \multicolumn{1}{|c|}{ Description } & \multicolumn{2}{|c|}{ Cycle } \\
\cline { 3 - 4 } & & I & II \\
\hline 1 & Average value & 82.30 & 81.30 \\
\hline 2 & Number of Taskas $(>70)$ & 9 & 10 \\
\hline 3 & Number of Unfinished Students & 1 & 0 \\
\hline 4 & \% Classic Exhaustiveness & 90 & 100 \\
\hline
\end{tabular}

TABLE XII. STUDENT PSYCHOMOTOR LEARNING RESULTS

\begin{tabular}{|l|l|c|c|}
\hline \multirow{2}{*}{ No. } & \multicolumn{1}{|c|}{ Description } & \multicolumn{2}{|c|}{ Cycle } \\
\cline { 3 - 4 } & & I & II \\
\hline 1 & Average value & 72.80 & 83.00 \\
\hline 2 & Number of Taskas $(>70)$ & 7 & 10 \\
\hline 3 & Number of Unfinished Students & 3 & 0 \\
\hline 4 & \% Classic Exhaustiveness & 70 & 100 \\
\hline
\end{tabular}

Referring data cognitive learning outcomes can be seen the increase of students' cognitive learning completeness in the course of machining practice with the application of project-based learning model from the cycle I to II, with the percentage of classical completeness cycle I by $90 \%$ and cycle II of $100 \%$. This suggests that the application of a project-based learning model to improve the machining skills of the machining process can be expressed "competent".

Referring the data of psychomotor learning result can be seen the increase of students' psychomotor learning comprehension value in the course of machining practice with the application of project based learning model from cycle I to I, with the percentage of classical completeness cycle I $70 \%$ and $100 \%$ cycle II. This suggests that the application of a project-based learning model to improve the machining skills of the machining process can be expressed "competent".

Based on student learning outcomes from the cognitive, and psychomotor, domains that have been described above, it can be said that the application of project-based learning model has been proven to improve student skills in machining process work. Through a project-based learning model, the inquiry process begins with raising a guiding question and guiding learners in a collaborative project that integrates the various subjects (curriculum) in the curriculum. At the time the question is answered, the learner can directly see the various main elements as well as the various principles in a discipline that is being studied. PjBL is an in-depth investigation of a real-world topic, it will be valuable to the attention and effort of learners.[2]

Learning model used by teacher is one of the factors that determine whether or not the learning objectives are achieved. Appropriate learning model will determine the quality of learning. Project-based learning model conducted by researchers in accordance with social learning theory and constructivism Vygotsky learning theory [2]. Social learning theory suggests that most humans learn by observing and remembering the behavior of others. While Vygotsky states that learning occurs through social interaction, through the help of teachers or colleagues who are more capable, 
specifically provide guidance or scaffolding is to provide support for learning and problem solving. Such support can be guidance, warning, encouragement, detailing the problem into steps, examples, or other actions that allow the student to grow independently as a learner.

\section{CONCLUSION}

Based on the results of data analysis and discussion, the researchers can conclude that the implementation of projectbased learning model was proven to improve the machining skills of machining process. This is based on the observation of lecturer's activities, students' activities and students' learning outcomes with the following description. The most dominant lecturer activity in cycle I and cycle II is to monitor students in project completion, $45 \%$ in the first cycle and $55 \%$ in the second. This shows that the role of lecturer was as a facilitator so that students become more dominant during learning. The most dominant student activity is completing the project by monitoring the lecturer, $42 \%$ in the first cycle and $46.5 \%$ in the second cycle. This indicates that the lecturer acts as a facilitator so as to give a lot of time to the students to develop their own potential, especially in machining skills. The completeness of students' cognitive learning results in classical increase from cycle I to II, with the percentage of classical completeness cycle I by $90 \%$ and cycle II by $100 \%$. As for the completeness of psychomotor learning outcomes students in class also increased with percentage of cycle I $70 \%$ to $100 \%$ in cycle II. This shows that student learning outcomes can be declared "competent".

\section{REFERENCES}

[1] Asabere, dkk. 2012. "Use of Information \& Communication Technology (ICT) in Tertiary Education in Ghana: A Case Study of Electronic Learning (E-Learning)". International Journal of Information and Communication Technology Research. Vol.2, No.1, January 2012, pp. 62-68.

[2] Bacer, Areca. dkk. 2011. Project-based Learning Model, Relevant Learning for the 21st Century. USA: Pacific Education Institut.

[3] Blumenfeld, Phyllis C. 2011. Motivating Project-Based Learning: Sustaining the Doing, Supporting the Learning. Journal Educational Psychologist Vol. 26, Issue 3-4 pp 369-398.

[4] Gronlund, N.E. 1982. Contrusting Achievement Test: Third Edition. New York: Prentice-Hall Incorporation.

[5] Krar, S.F., Amand, J.W., Oswald, J.E.St., 1996. Machine Tool Operation"s, McGraw Hill, USA.

[6] Ratumanan, T.G. dan Lourens, T. 2003. Evaluasi Hasil Belajar yang Relevan dengan Kurikulum Berbasis Kompetensi. Surabaya: YP3IT Kerjasama dengan Unipress.

[7] Sadiman, dkk. 2008. Media pendidikan. Jakarta: PT. Raja Grafindo Persada.

[8] Slavin, R.E. 1995. Cooperative Learning, Theory and Practice. Boston: Allyn and Bacon Publisher.

[9] Sudjana dan Rivai. 2005. Media Pengajaran. Bandung: Sinar Baru Algensindo.

[10] Tim Pelatih Proyek PGSM. 1999. Penelitian Tindakan Kelas (Classroom Action Research). Departemen Pendidikan dan Kebudayaan Direktorat Jenderal Pendidikan Tinggi Proyek Pengembangan Guru Sekolah Menengah IBRD LOAN NO. 3979 IND. 